\title{
Beyond the first glimpse (Analysis of the economic policy in Hungary from 1998-)
}

\author{
ISTVÁN CSILLAG*
}

Keleti Károly Faculty of Business and Management, Óbuda University, Tavaszmező u. 17, H-1084, Budapest, Hungary

Received: October 03, $2019 \bullet$ Revised manuscript received: January 15, 2020 • Accepted: May 08, 2020

(C) 2020 The Author(s)

\begin{abstract}
There is a sharp contradiction between the economic performance of the Hungarian government of Victor Orbán and the institutional framework (toolkit) by which the seemingly stellar performance of the Hungarian economy has been achieved. It looks like as if the economic playground of the government (disciplined fiscal policy, unorthodox monetary policy and contradictory institutional system) and politicalinstitutional order built by the same government during the last ten years, represent two different worlds. This paper provides a possible explanation to resolve this contradiction by identifying reversed relationship between tools and goals of economic policies. The genuine, hidden but most important goal of the present Hungarian government is to make Orbán and his political family wealthy and make their enrichment legitimate. In disguise of a public policy to achieve this (private, personal) goal, this government needs absolute and uncontrolled power certified by the scenery of the parliamentarian democracy. This private effort should be falsified, which could be achieved if his government pretends that it wants to pursue a disciplined economic policy.
\end{abstract}

\section{KEYWORDS}

economic policy, economic institutions, centralized system of decision-making

\section{JEL CLASSIFICATION INDICES}

B2, B5, P2, P3, P5

*E-mail: csillagik@gmail.com 


\section{INTRODUCTION}

This paper analyses the relationship between macroeconomic goals and tools from a reversed aspect. I deliberately break with the standard assessment of economic policy, based on the evaluation of macroeconomic performance (GDP growth, inflation, unemployment, fiscal and current account deficits) in the light of economic intentions and the goals of the Hungarian government. I examine to what extent these seemingly impeccable achievements stem from the economic policy of the Orbán-government. In the economic and political literature, the performance of the Hungarian government is ambiguous, at least. In my analysis of the economic policy of the political regime I applied the thesis of Pigou (1920/2001) about economic welfare. According to Pigou, economic welfare increases if the size of national income increases without worsening the distribution, or economic welfare increases if distribution improves and the size of national income does not decline. I found that the present regime is not able to meet these requirements, for this reason there should be other goals of what the government would like to achieve than the increase of economic welfare of the population. Beyond that contradiction the most embarrassing fact is that almost all macroeconomic analysts acknowledge the improvement of macroeconomic indicators, the opposition blames Orbán, that he has destroyed most, if not all democratic institutions and the system of checks and balances, an autocratic state has replaced democracy, and corruption and state capture has been completed to an unprecedented industrial extent (Körösényi 2015; Csillag, 2015). In my paper, I show that these two interpretations belong together. They together explain how the economic policy of Orbán is working, they are intertwined halves of the same system. The contradiction is apparent between the macroeconomic and political interpretations as both kinds of analysis start from the wrong end. Everything just fell into place if we start this analysis from a reversed aspect, instead of analysing the outcomes according to the standard evaluation, I try to reveal those underlying goals which could be achieved only if the economic policy is able to produce good results by improving indicators. Improving indicators are not goals to be achieved but necessary means to accomplish the political vision of the regime.

Hence, I concentrate on the genuine (underlying) goals of the Orbán's government and I demonstrate that macroeconomic policy and performance are the means for realizing the real intentions, the vision of Orbán's political family: getting rich and keeping power for legitimation of enrichment. Notwithstanding these twin goals and their impact on the Hungarian political system (the Rule of Law exchanged for the Law of Rule) could be demonstrated and analysed by political studies as well (Bozóki 2012; Ungváry 2014; Körösényi 2015; Magyar - Vásárhelyi 2016; Szelényi 2019). It is worthwhile to start the political economy analysis of the macroeconomic agenda from the other end, from interestedness of the ruling political class in achieving good performance of the economy to hide the genuine political goals.

Analysts are victims of Orbán, they stand for their studies in the cage of tradition (Acemoglu Robinson 2019), and they are not being able to combine the aspects of the two disciplines, as in the Orbán's system goals are replaced with means, in order to achieve the genuine, hidden goals: to keep power and get wealthy. To realize this main goal, it is an advisable precondition to improve macroeconomic indicators, to gain and maintain the benevolence of creditors and rating agencies. I try to give evidence that even if the macroeconomic performance of Hungary is improving it is not the direct result, even less the genuine objective of the economic policy of the regime. It is the side product of public robbery behind falsified democratic institutions (Acemoglu - Robinson 2005), keeping them as a Patomkin village only, because it is the precondition for the uncontrolled 
utilization of public money and state-owned assets. On the top of that the improvement of the present-day economic performance - overemphasizing consumption at the expense of savings and investments - at least weakens, even destroys the basic factors (productivity) of future growth.

\section{THE HIERARCHY OF REAL (GENUINE) OBJECTIVES OF ECONOMIC POLICY}

When analysing the economic policy and the performance of any country, it should be determined what the aspects of evaluation and what the basics of comparison are? Usually the analysis is based on the same values, as governments' economic policy represents the compass to achieve objective public welfare (Acocella 1998) of the population which is based on the macroeconomic fundamentals like rate of growth, unemployment, inflation, fiscal and current account, size of the public debt and external debt, and investments especially FDI. The leading indicators of macroeconomic fundamentals are the starting point, as targets, or as a result and as a precondition to pursue the goals of the economic policy.

In case of the Hungarian government there is a very tricky situation, as economic fundamentals play simultaneously the role of externalities and preconditions helping to achieve the genuine (underlying) goals of the Orbán-government: keep power for eternity, make the political family of Orbán have an access to public money and to become the most wealthy and highest income group of the country (Buckley - Byrne). The consequence: hierarchy of the underlying goals has to be reconstructed.

Application of the traditional tools of analysis would only show an illusion, while the reality can be traced behind the fundamentals of macroeconomic policy. It is a curious duality of goals and instruments. Traditional goals, such as the rate of growth, the low level of the deficit are prerequisites and are instruments to achieve the real political goals.

The most important goals of the Hungarian government are:

- to preserve the opportunity to pursue an independent, uncontrolled, sovereign economic policy. The interim target is to get rid of any outside interference, the very thorough control of the IMF, excessive deficit procedure of the EU, and too close surveillance of the European Commission (EC). As a precondition to achieve this sovereignty, Orbán should avoid serious fiscal and current account deficit (twin deficit), to produce sustainable growth and to minimize financial risks (Kopits 2013);

- to gain access to the uncontrolled and unrestricted utilization of public money (Hungarian and EU taxpayers' money included transfers from the EU Cohesion Funds) and public assets. The independent and sovereign economic policy itself is the prerequisite to achieve this goal, but more over the institutionalization of the unrestricted and uncontrolled utilization of public money and assets requires switching off outside (IMF/EU) and inside control (Opposition and even the Parliament) (Schering 2015). Elimination of outside control was achieved by pursuing a seemingly disciplined fiscal policy, and (statistically) pretended production of the expected necessary fiscal indicators (e.g. public debt denominated in FX is measured on that very date at which the rate of exchange is the strongest for the HUF). Elimination of inside control was the change of Constitution, overcentralization (Kornai 2017) and amendment to the law on the State Finance Law (ÁHT), to the power of the Constitutional Court, and to the Law on Fiscal Council;

- to redistribute income and wealth of the country for the benefit of Orban's political family, without the risk of excessive deficit procedure. Preconditon to make it happen is unrestricted 
access to the EU funds - to finance and keep: a) additional demand (higher rate of growth), b) moderate level of budget deficit, c) easy accumulation of foreign exchange reserves, and d) a creative new technique to utilize the profit of the Central Bank (MNB) bypassing the authorization of the Parliament. Through this way the MNB is financing either fiscal goals instead of the government (Foundation of the Bank), or indirectly financing the deficit of the state budget (Foundations of the Bank are buying into bonds) which is absolutely forbidden by the European (ECB) standards (Political Capital 2018);

- to build and to preserve the unconditional support of a significant part of the society based on 2/ 3 majority of the MP-s in the Parliament. Precondition is to differentiate among the voters, who are eligible to much lighter taxation based on reduction of tax-wedge (introduction of a flat tax with tax-allowances: reduction of personal income tax (PIT) depending upon number of children); and for other people who are dependent on social policy of the government, because they are able to survive only if they behave according to the expectation of the government. The reduction of social aid and unemployment benefit resulted not only in the opportunity to build unconditional support of the poor people for Orbán, but simultaneously diminishing the rate of inactivity, and some increase of labour supply;

- to create a new duality in the market sector (previously SME versus Multinationals; now enterprises which are realizing their income on the domestic market and for those who are exporting). Owners of enterprises working on the domestic market should belong to Orbán's political family. Precondition to achieve this new duality is abolition of neutral taxation and the introduction of heavy, special sectoral taxation on those sectors which earn income on the domestic market of Hungary and where enterprises are in foreign hands, in order to achieve that ownership rights might be passed (K-monitor 2020; Hungarian spectrum 2013) to the beneficiary owners (political family of Orbán). Exporting companies are controlled by signing strategic alliance contract with the government to remain in Hungary and behave according to the government expectations. These lead to growing involvement of the state in corporate sector and distortion of market competition;

- to rule present day and do not bother what will happen tomorrow! Instrument utilization of the EU membership, flood of available money on the world money market, environment of low inflation and manoeuvring between East (Russia) and West (EU), the USA and China.

\section{STRENGTHENING FISCAL DISCIPLINE FOR GETIING RID OF CONTROL FROM OUTSIDE}

At the time when Orbán took power in 2010, Hungary was under excessive deficit procedure of the EU. EU and the IMF had the right to control all steps of the government. After the outburst of the financial crisis in 2008 the Hungarian government was very close to fiscal insolvency and was forced to ask for immediate financial help. The FX reserves of the MNB were too low to finance the imports and interest payments, 20 billion euros worth bail-out credit-line was offered by the IMF, the EU and the World Bank, from which 14.2 billion euros has been borrowed.

The Hungarian fiscal crisis situation was due to the fact that the results of the 1995 adjustment (the so called Bokros's package introduced, and named by the Minister of Finance in 1995) had been squandered between the years of 2001 and 2008, as consecutive governments 
were spending enormous sums from the state budget. The fiscal expansion was counterbalanced by restrictive monetary policy of the MNB in the form of raising the rate of interest, but it did not stop the households, the non-financial sector and the banks to borrow from the international markets as money-markets were liberalized. The stabilization program introduced in 1995 had made it possible for the next 7 years (until 2002) to achieve robust and sustainable growth, reduction of the twin deficit of state budget and current account, and the size of public debt also diminished as massive privatization had resulted in large fiscal revenue. Governments after Bokros were not only conceited, but as they represented two different political sides, they competed with each other in promising even larger wages, larger pensions (13 month bonus pension), and refinancing of state-owned enterprises (e.g. railways). It was not only a tug of war, but a war of attrition as the two sides undermined the possibility to pursue rational economic policy (Alesina - Perotti 1994). The first Orbán government (1998-2002) started to raise minimal wages $(200 \%)$ and the salary of the civil servants, introduced massive interest subsidies on mortgage loans and built motorways avoiding the transparent financing of them from the budget. The next social-liberal government introduced the 13 month bonus pension, the 50\% increase of wages for all public employees, minimum wages tax-exempt, and started heavy subsidization of gas and electricity. The consequence was massive increase in the budget deficit and although huge access was created, which is a typical feature of a pro-cyclical economic policy in boom, the rate of growth did not reach record levels (Figure 1).

The excessive promises and the real wage expansion convinced the public that it was time to borrow as income of the population was also increasing to cover the rising costs. The consequence was that private debt jumped from $49 \%$ to $118 \%$ of GDP, public debt from 55 to $78 \%$ of GDP and as the NBH had no choice, but to pursue a very tight monetary policy ${ }^{1}$, because the new socialist-liberal coalition continued the pro-cyclical economic policy of the first Orbángovernment. Although the seemingly restrictive monetary policy was emphasized, borrowers went to the liberalized international money markets or to commercial banks, who had a direct credit from their mother banks, so the final funding was in foreign exchange, as it was shown by Wojciechowski's Orbanomics (2017).

The increasing twin deficits and the doubling of debt (Bokros - Dethier 1998) had resulted the repeat of stop and go policy. The stop and go economic policy was reminiscent to the previous socialist (reform-communist) period, when in the year of the actual Communist Party Congress there was a push to show the drive of the Congress' decisions (GO), but as the higher rate of growth was achieved by running into higher foreign debt, soon restrictions started (STOP). The fluctuation of ups and downs continued after the transformation of the economic and political system, even at a much higher degree because of the serious transformational recession. In Hungary there was no legal constraint to avoid high budget deficits (contrary to Poland), or any inclination of the political class to save taxpayers' money. Only the EU convergence criteria pushed the government to fiscal discipline, and very lately, only in the year of the crisis (2008) an independent Fiscal Council (FC) was established by the Parliament and new rules were adopted for pursuing transparent and sustainable fiscal policy. This, independent FC was led by an internationally well-known expert of the transparent fiscal policy, and for his

\footnotetext{
${ }^{1}$ There are quarrels about that it is worthwhile to counterbalance the very loose fiscal policy by a very tight monetary policy in a small, open, liberalized country, but it is always a signal against the risk of overheated economy.
} 


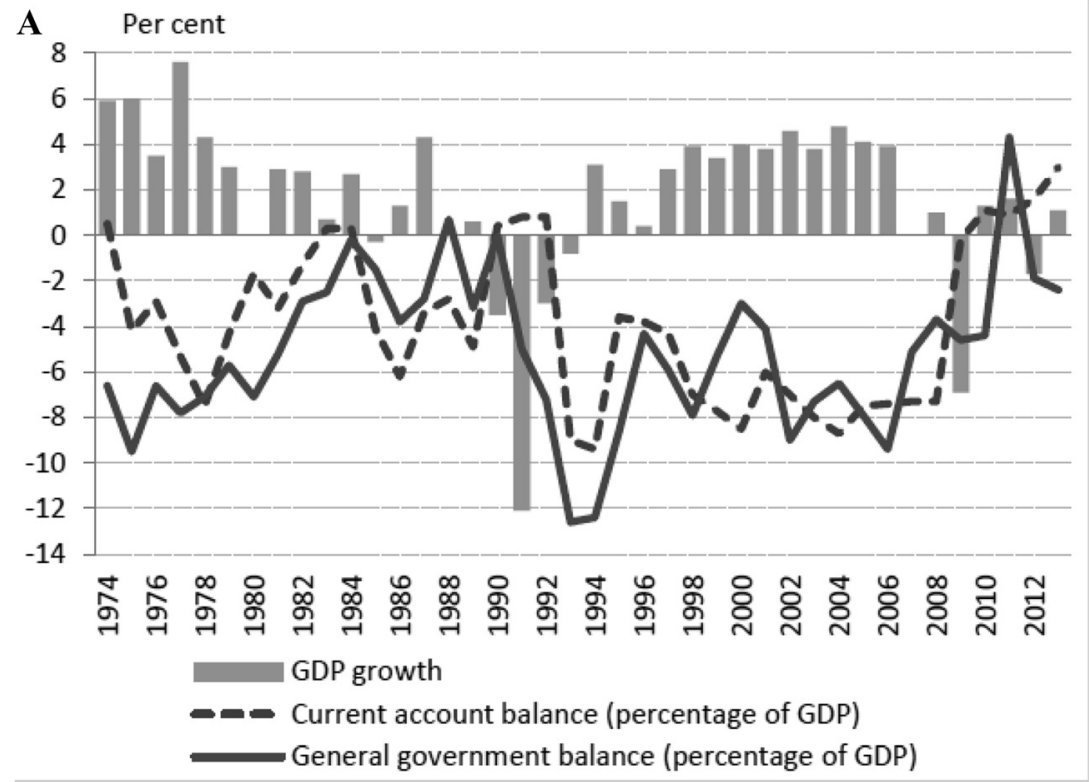

Source: HCSO.

B

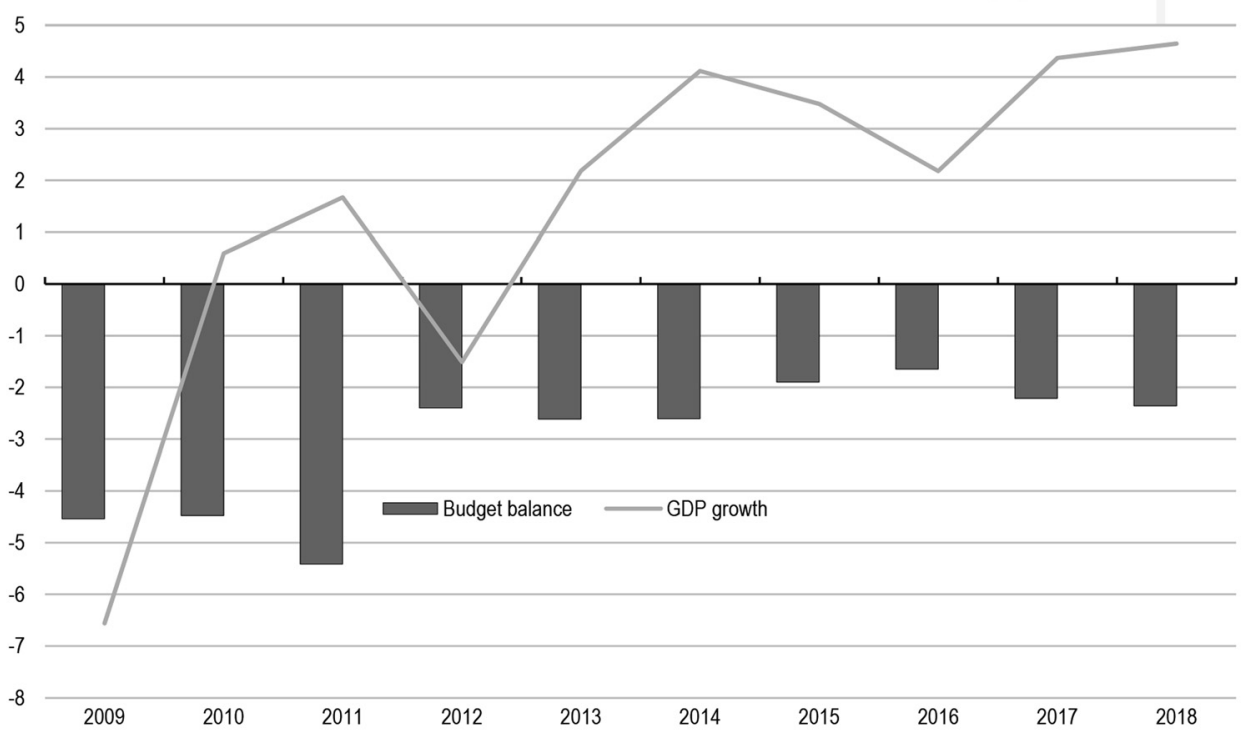

Source: OECD.

Figure 1. A. Economic growth, external balance and budget balance in Hungary since 1974, B. Economic growth and budget balance in Hungary, 2009-2018 
disposal there were excellent experts as personnel. Unfortunately, the independency of the Council, its personnel and its previous function was abolished by the second Orbán government in 2011, instead of somebody as President, a triumvirate was nominated from the minister of finance, the governor of the MNB and one more person, who are also faithful to Orbán, while there are no personnel or experts at all, for the disposal of the President of the FC.

Although Orbán wanted to get rid of all kind of control over his economic policy of his second government (from 2010), but after he won the general elections in 2010 he had to realize immediately that the promised large-scale and radical tax-reduction cannot be adopted against the will of the EC, because it could result in a very high fiscal deficit (8\% of the GDP) again. Instead of increasing the deficit further, he was forced to continue the economic policy of his predecessor, Bajnai Government, that he blamed for everything.

In this situation he implemented a threefold strategy: on the one hand he continued the "disciplined" fiscal policy (Kopits 2012), on the other hand he started to make some room for manoeuvring with introduction of new extraordinary crisis-, sectoral taxes, all of them are the burden of those branches of industry which are under the control of multinationals and generate their income in the domestic market. The third element was that the government hid its genuine goals and real measures (extra taxation and fiscal disciplined restrictions) by proclaiming that it would introduce public finance reforms (from healthcare to pensions, from education to social aid). Orbán and - according to his own words his right-hand - György Matolcsy, the Minister of Economy were always very keen to put the goals of their economic policy and the necessary steps to be taken, under the umbrella of high-sounding names of the Hungarian heroes so as the special programs and economic plans become well identified by these names (Hungary Today 2018. Orbán.V.). In this case they introduced the SZÉLL-plan - named after a Prime Minister of Hungary before the WW I - in which main and well-announced goal was to reduce the public debt for getting rid of the control of bankers, but among them control of the IMF, to repay the IMF loans (IMF 2015). This goal in reality was fulfilled in 2016, as the last instalment of the loan was paid back in the summer of that year, but the underlying reason of the fight against the IMF was blamed as the only cause of the necessary restrictions (IMF 2016).

Orbán played the role of the liberator and saviour of the country. In disguise of this role, Orbán had introduced new sectoral taxes, which had amounted $2 \%$ of the GDP, while public expenditure items (from pension to health care, from education to social aid, or to local governments) were cut back also around $2 \%$ of the GDP. The restrictions were larger than that of the Bokros package in 1996. Among these measures the most important in size and in significance was the forced dismantlement of the mandatory private pension pillar of the pension system (Bokros 2014). As a result of this measure the social security contribution of the members ( $8 \%$ or, $1 / 4$ of the whole payroll-tax) went into the state budget instead of the private pension funds, which alone had 1\% of GDP net revenue-effect. Moreover, in addition to the increased flow of current revenue into the budget, the stock of the already accumulated pension fund was also expropriated. Significant part of these savings was used to decrease the current deficit of the budget, while the remaining part was used to reduce public debt, notwithstanding these efforts it remained over $80 \%$ of GDP (Eurostat). The confiscation of the accumulated mandatory private pension savings, had crushed the private, independent pension funds and the self-care spirit in the population (Bokros 2013.). This was the first step to build the economic basis of an autocratic system of Orbán. In addition to the size of the private pension savings, the significance of this measure signalled what would happen if Orbán was able to realize his vision. 

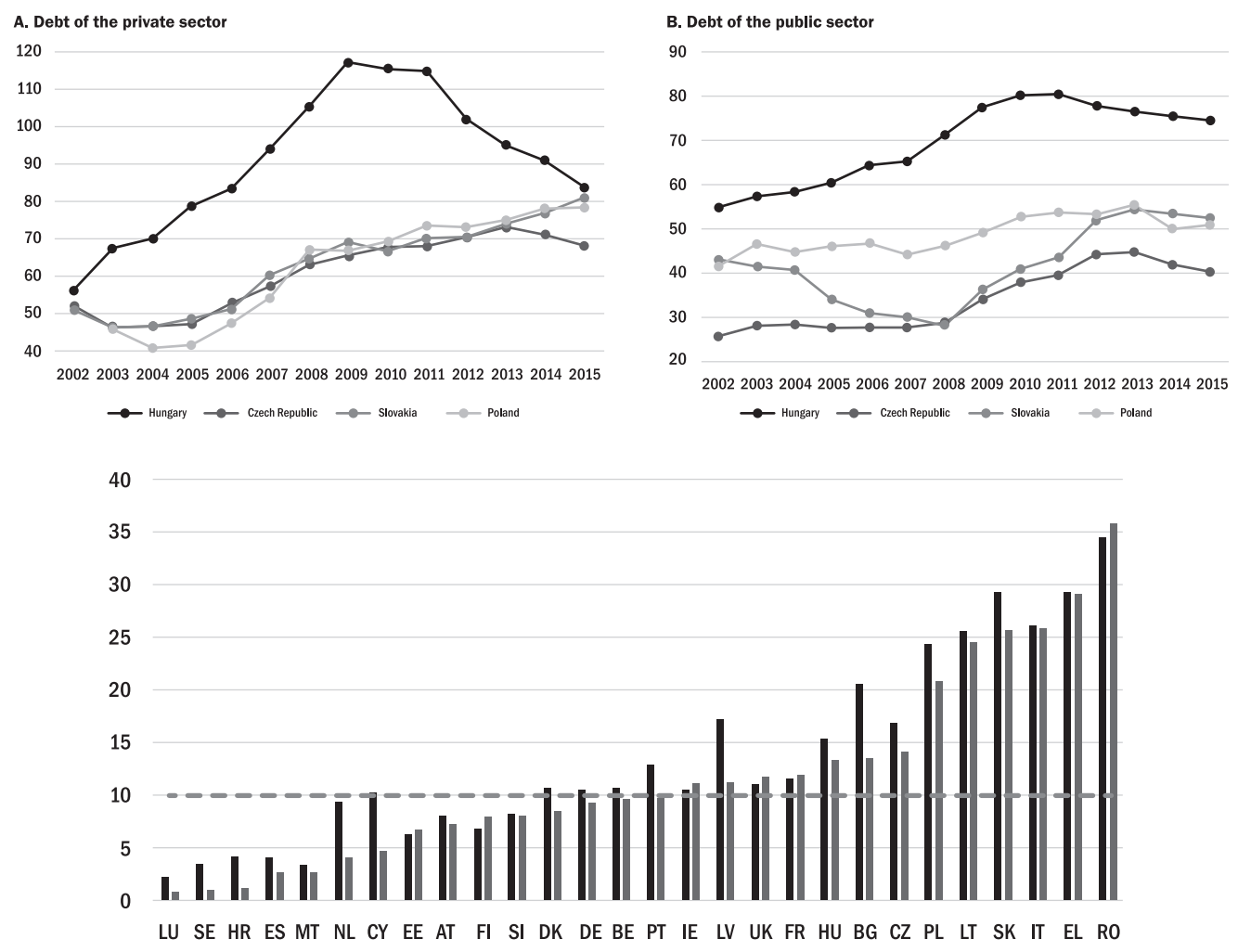

$2015 \quad 2016 \quad--$ median

Source: Own calculations.

Figure 2. Debt of the private sector and public sector in the period of 2002-2015 (\% of GDP), Figure 2.1 VAT GAP as a \% of the VTTL in EU-28 Member States 2016

The size of the adjustment was enormous : $1 \%$ of the GDP from the payroll-tax, $2 \%$ of the GDP from special sectoral taxes, $2 \%$ of the GDP from savings of the welfare (education, health care, pensions) and on the top the previous extraordinary revenue from the confiscated private pension funds' savings (around 4\% of GDP). The impact of the special, extraordinary, "crisis" sectoral taxes is enormous by itself, because it was just twice as much (in bad years) or at least the same as the revenue from the normative profit tax in the budget. In this way the government was able to force the owners of these enterprises to sell their stake to the political family of Orbán. The new revenues and restrictions of the expenditures of the budget resulted in the disappearance of the high deficit of the budget ( $8 \%$ of the GDP), without taking into consideration the influence of the EU transfers. The confiscated private pension fund had resulted in an extraordinary large surplus in the statebudget in the year of confiscation (one off item) - instead of the expected deficit. 
3.1. Sectoral tax receipts as $\%$ of GDP in Hungary, 2008-2018

\begin{tabular}{|l|l|l|l|l|l|l|l|l|l|l|l|}
\hline & $\mathbf{2 0 0 8}$ & $\mathbf{2 0 0 9}$ & $\mathbf{2 0 1 0}$ & $\mathbf{2 0 1 1}$ & $\mathbf{2 0 1 2}$ & $\mathbf{2 0 1 3}$ & $\mathbf{2 0 1 4}$ & $\mathbf{2 0 1 5}$ & $\mathbf{2 0 1 6}$ & $\mathbf{2 0 1 7}$ & $\mathbf{2 0 1 8}$ \\
\hline The financial sector & 0.05 & 0.05 & 0.71 & 0.70 & 0.33 & 1.47 & 1.48 & 1.17 & 0.92 & 0.76 & 0.74 \\
\hline Tax on financial institution & - & - & 0.67 & 0.66 & 0.30 & 0.46 & 0.46 & 0.44 & 0.25 & 0.49 & 0.00 \\
\hline Additional tax from financial institutions & 0.05 & 0.05 & 0.04 & 0.03 & 0.03 & 0.06 & 0.06 & 0.03 & 0.02 & 0.16 & 0.13 \\
\hline Financial transaction & - & - & - & - & - & 0.86 & 0.86 & 0.61 & 0.57 & 0.56 & 0.57 \\
\hline Tax on insurance companies & - & - & - & - & - & 0.09 & 0.09 & 0.09 & 0.08 & 0.08 & 0.03 \\
\hline Other sectoral taxes & 0.00 & 0.16 & 0.72 & 0.76 & 0.75 & 0.66 & 0.56 & 0.56 & 0.53 & 0.30 & 0.32 \\
\hline $\begin{array}{l}\text { Additional tax income from energy } \\
\text { companies }\end{array}$ & - & 0.09 & 0.06 & 0.06 & 0.02 & 0.18 & 0.11 & 0.12 & 0.12 & 0.05 & 0.05 \\
\hline Tax utility providers & - & - & - & - & - & 0.18 & 0.17 & 0.17 & 0.15 & 0.13 & 0.14 \\
\hline Tax telecommunications & - & - & - & & 0.04 & 0.16 & 0.17 & 0.16 & 0.16 & 0.06 & 0.06 \\
\hline Tax on advertising & - & - & - & - & - & - & 0.01 & 0.02 & 0.03 & 0.00 & 0.03 \\
\hline Other sectoral taxes sectoral & - & - & 0.56 & 0.61 & 0.58 & 0.03 & 0.00 & 0.00 & 0.00 & 0.04 & 0.02 \\
\hline Tax on company cars & - & 0.07 & 0.10 & 0.09 & 0.11 & 0.11 & 0.10 & 0.09 & 0.08 & 0.10 & 0.10 \\
\hline Total (\% of GDP) & 0.05 & 0.21 & 1.43 & 1.46 & 1.08 & 2.13 & 2.04 & 1.74 & 1.45 & 0.08 & 0.30 \\
\hline General Profit-tax & 1.8 & 1.4 & 1.2 & 1.1 & 1.2 & 1.0 & 1.2 & 1.6 & 1.9 & 1.60 & 0.90 \\
\hline
\end{tabular}

Source: Wojciechowski's (2017) and own calculations based on HCSO. 
In a system where private interest of the governing political group dictates, a public policy does not exist anymore, but to destroy a democratic system based on checks and balances and to become an authoritarian, one the most important tool is to gain total control over the state budget and all forms of public spending. To achieve this goal Orbán built his own power on two pillars: unrestricted control of the Parliament and abolition of any constitutional control channels outside the Parliament. Reduction of welfare spending affecting the vulnerable strata of society and special new sectoral taxes could be introduced only if the constitutional control did not exist. The IMF gave notices several times that fiscal consolidation was as important as preserving the trust of private investors and entrepreneurs: “The authorities' commitment to the fiscal targets under the revised Convergence Plan in 2012-2013 is welcome. However, a greater focus should be placed on achieving a more balanced fiscal consolidation, shifting away from the ad hoc tax measures towards streamlining public expenditures, while ensuring adequate support to the vulnerable groups. A smaller and more efficient state with strong and predictable policies would create better conditions for private sector led growth and reduce the tax burden over time. For 2013, additional measures will be necessary to secure the government's deficit target and put public debt firmly on a downward path" (IMF 2015).

Orbán wanted to control the financial sources of the opposition parties', which in most cases even in Fidesz ${ }^{2}$ were transferred from the sponsors in cash (special channels of the grey or black economy). To prevent this manoeuvring the Hungarian government introduced new measures: 1. All logistic activities performed and based on the road-transport should be reported in advance to the tax-authorities, who are able to control if VAT had been reported or payed in. 2. In retail trade it became compulsory to record and report all receipts directly to the taxauthority via a newly created direct-internet based network of cash-registers. The side-product of this special prevention against the opposition parties (as almost all parties are able to make money through manipulated invoices paid in cash) was that the VAT-Gap (difference between size of the calculated VAT obligations and effective VAT payments) has diminished largely. Previously the difference between calculated VAT obligations and effectively paid VAT was $22 \%$ of all VAT obligations confessed, and it went to the $14 \%$ of it. (The EC has informed the public about this in 2018 in a special study of CASE - Center for Social and Economic Research.) (CASE 2017).

The change is impressive in comparison to the neighbouring countries because it is more than $0.5 \%$ of the GDP.

\subsection{Uncontrolled and unrestricted public spending}

The Hungarian election system used to be a mixed system of list of parties and individual constituencies. This mixed system - a compromise to avoid fragile and multiparty governments and the winner takes it all - gave premium mandates to those parties, who were able to surpass the threshold of $5 \%$ votes. During the last ten years Fidesz amended this system in such a way that premium mandates could be obtained even to the winner party. The consequence of this

\footnotetext{
${ }^{2}$ Fidesz - Hungarian Civic Alliance is the right-wing populist ruling party in Hungary. Founded in 1988 as a liberal youth party opposing the ruling communist government, Fidesz has come to dominate the Hungarian politics at the national and local level since its landslide victory in the 2010 national elections with an ethno-nationalist agenda. Viktor Orbán has been the leader of the party for most of its history, including the liberal period.
} 
amendment was that Fidesz got $2 / 3$ of the mandates in the Parliament, with only $43 \%$ of the votes, again in 2014 . The $2 / 3$ majority enabled the government to introduce a special legislation of fundamental laws (which can be amended with $2 / 3$ majority only), and to introduce a new Basic Law instead of the previous Constitution. This new Basic Law restricted the power of the Constitutional Court. It was specifically stipulated that any bill concerning the state budget must not be revised by the Constitutional Court, as long as the size of the public debt does not go under 50\% of the GDP. Orbán's quite innovative and creative institution building has resulted a new type of illiberal governance utilizing the inherited democratic framework (Sárközy 2019).

As in his party, Orbán as the president has the power to select all candidates for the general election, he has a personal veto right when selecting the candidates of the institutions representing the checks and balances including members of the Constitutional Court, the State Audit Office (SAO) and the FC. Hence, there is no chance to pursue any fiscal policy against Orbán's will. The opposition parties do not have the strength to achieve any modification in the budget, they are not able to form any special parliamentarian commission to supervise the fulfilment of the targets of the budget, or to oversee the public procurement processes. The Members of Parliaments (MPs) of Fidesz are under the thumb of Orbán. To avoid any dispute in his own party, in his own government, or in the Parliament, the bills are introduced by the name of individual MP's instead of the agencies, or ministers of the government, or the Government itself. Through this way he is able to avoid the disputes, because the bills almost in all cases are adopted according to the emergency proceedings, which means it takes 48 hours from the introduction of the bill until it is adopted. Orbán has chosen this individual MP's initiation, because the public is not able to be informed about the plans of the government, as it is the case when governmental agencies, ministries are preparing and conciliating the bills at first, then, the parliamentary commissions and at the end the full session of the Parliament. This new knowhow of Orbán's rule not only blocks the normal reconciliation among the various government agencies, but his fellow MPs also do not have the possibility to control what is happening in advance. This procedure enables the government to avoid any predictability and transparency of the economic policy. This is a new technical version of "illiberal democracy" (Zakaria 1997).

Beyond the absolute centralization of decision making at the level of the Parliament and government, Fidesz brought into fashion an early bird adoption of the state budget. Budgets are now adopted by the Parliament in June, when the data of the former year is still not available to apply it as the baseline of the budget, therefore no one is able to speculate about the expected execution of the appropriations. The consequence of this early bird adoption is that during the year of execution there are at least 3-4 amendments to the budget which gives absolute power to the government and makes the Parliament helpless, while transparency and predictability is diminishing continuously. But the early-bird adoption of the budget is not enough to achieve an absolute control over public spending. The law on the state budget proceedings was also changed. Today it is no longer compulsory - as previously, according to the responsibility of the Parliament - to ask parliamentary approval for modifications of the budget, if it does not exceed the $10 \%$ of the annual budget (5\% of the GDP in size, which is an enormous number). As ceiling of the modifications is high - around that $10 \%$ limit - the government has the absolute power to change all appropriations.

We must add that the Law on Public Procurement also changed. Limits of compulsory public procurement has been increased to the level of very big projects, while smaller ones are to be executed without any publication and transparency. 
The two bodies, the SAO and the FC which have the right to control the government public spending are no longer independent. The President of the SAO was an MP of Fidesz, the President of the FC does not have any administrative support and he was nominated by Orbán according to his previous loyalty to him (Kopits 2013).

There is another extremely curious feature of the operation of the FC. According to the Law on FC the President of the FC could control the public policy in an extraordinarily strong way. The President could force the dissolution of the Parliament if it is not able to adopt the next year state budget within a predetermined period. In this way the President of the FC is able to force new general elections. If I add to this very strong power that the FC President is representing Orbán's personal decision, as he is elected by the Parliament suggested by the President of the Republic, who is one of the best friends of the Prime Minister.

\subsection{Building and presenving political base of Orbán}

It is well-known that to maintain the political base of any government there are three things to be achieved: low level of unemployment, robust growth of the economy and relative well-being of the clientele.

\subsection{About causes of low unemployment}

Low level of unemployment is the result of opening the European labour market, together with cutbacks on social transfers of the public works program and the influence of the economic growth. This extraordinarily low level of unemployment reflects several important tendencies. First, emigration (according the guesses $400-500,000$ or $10-12 \%$ labour force) to other EU countries resulted in a huge drop in unemployment. This could happen because the derogations against opening the EU labour market lost their validity just after the financial crisis of 2008 . Due to the recession in Hungary and the enormous differences in wage level, the government forced unemployed people to find jobs in abroad. This number is close to $10 \%$ of the whole labour supply of Hungary, but considering the family-members also, it is almost $7-8 \%$ of the Hungarian population, who live in abroad at least temporarily (Figure 3 ).

The other reason for the very low level of unemployment: unemployment benefits were cut and the entitlement period was shortened which forced the unemployed to find jobs on the domestic labour market as soon as possible. The long-term unemployed were forced into the public works (community service and public service) program. This program offers temporary (3-6 months) jobs to the unemployed, and it is administered by local authorities. It helps to achieve low level of unemployment in the labour statistics. At the same time people in the public works program became dependent on the good-will of the local mayors, which is one of the instruments to motivate them vote to Fidesz. As in the small villages and towns the polling districts are small, persons could be identified, controlled and manipulated, even if the ballots are secret, as the number of votes could be compared to the number of the population, who appeared on the spot (Byrne 2015).

The third factor for the low level of unemployment is economic growth. It started in the end of 2013. Thanks to the EU Funds, the transfers created robust growth after seven years of misery and increased the labour demand in the competitive sector by almost 200 thousands employees. If I add these three factors their influence was more than ten percentage points rise in the activity rate and employment rate in the statistics of the labour market. In the years of general 


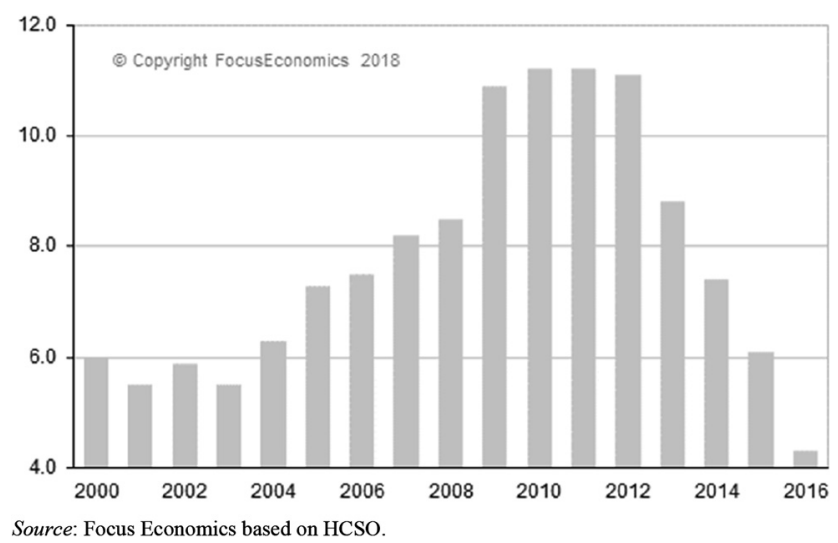

Figure 3. Unemployment in Hungary, 2000-2016

elections (2014 and 2018) the number of people in the public works program was between 150 and 200 thousands, while people working abroad was between 350 and 450 thousands. Hence, very low level of unemployment was achieved.

\subsection{About robust rate of growth}

Beyond the extraordinary low level of unemployment, the rate of growth was made impressive in the years of general elections. The sluggish economic performance of Hungary - in comparison with other new EU members, especially the Baltic countries and Poland - just one year before the general elections of 2014 and 2018 improved again due to the huge transfers of the Cohesion Funds of the EU. Between 2013 and 2015, and again 2017-2018 the size of the transfers exceeded 5\% of the GDP which is almost twice as large as the average of the other new member countries.

Hungary was able to keep pace with other Visegrád countries (Czech Republic, Slovakia and Poland) until 2005 (Figure 4).

From the end of 2006 (after general elections), restrictions had to be introduced because of the very high deficit of the budget ( $8.5 \%$ of the GDP). The suboptimal mixture of measures slowed down the rate of growth (Surányi 2018). Worldwide financial crisis of 2008 and the necessary crisis-management measures had a negative effect on the economic performance, too. There was a serious and long-lasting recession until 2013 (year before the next general election). Then the Orbán-government started to exploit all sources of the available EU funds and even started to pay advanced payment to the winners of the tenders, involving the EU-funds. In other countries the utilization of the EU funds does not exceed 2-3\% of the GDP/year (between 2010 and 2017), while in case of Hungary it was around 5\%. This intensive drawing down of funds resulted in robust growth. This can be traced from Figure 5.

During the time of the second and third Orbán governments (2010-2018), Hungary has received an enormous amount of money from the EU. It is 3.5-4.0 per cent of the GDP on average each year. But in the years of general elections this amount was larger than $5 \%$, which 


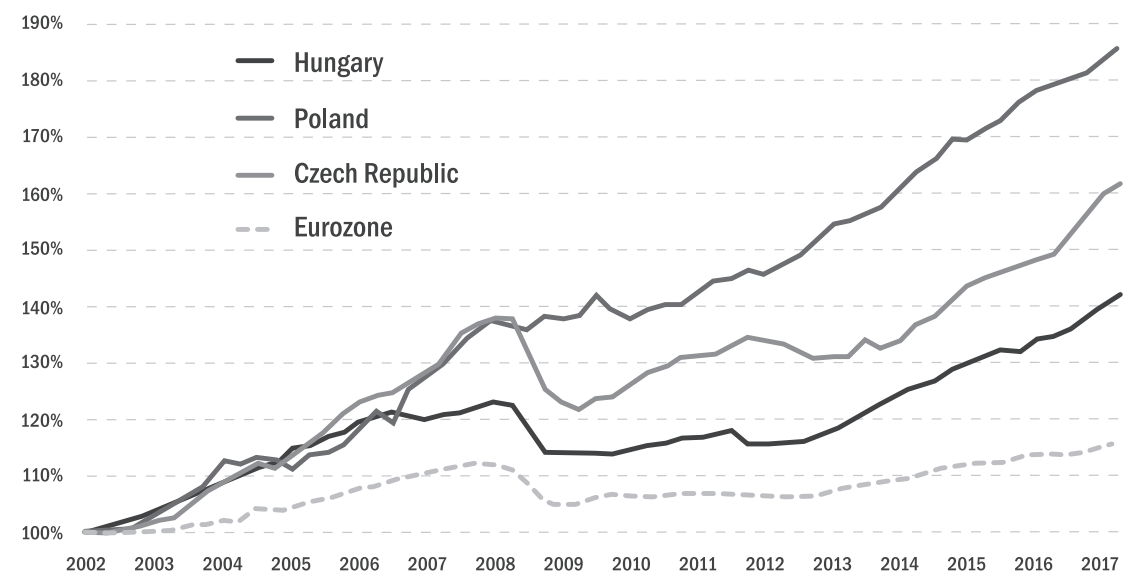

Figure 4. GDP growth/per capita of working age population

presented a very sizeable additional demand to make the rate of growth become very spectacular to the voters. This additional demand had four different consequences on the Hungarian economy: 1.) Almost $1 / 3$ of the government investment was financed by the EU funds; 2.) Deficit of the state budget (Csillag 2013) has diminished by 2-3 per cent of the GDP each year; 3.) Rate of growth became much higher taking into consideration the additional demand (potential growth is between 1.5 and 2.0\%); and 4.) Hungary was able to save at least 20-billion-euro worth of FX reserves (Figure 6).

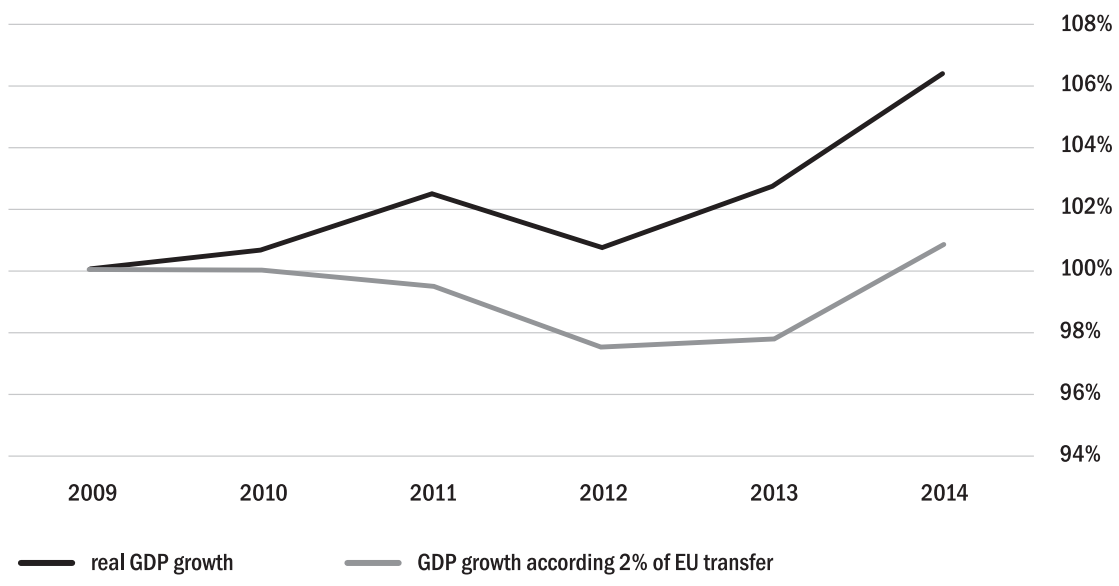

Figure 5. Economic performance of Hungary, 2009-2014 


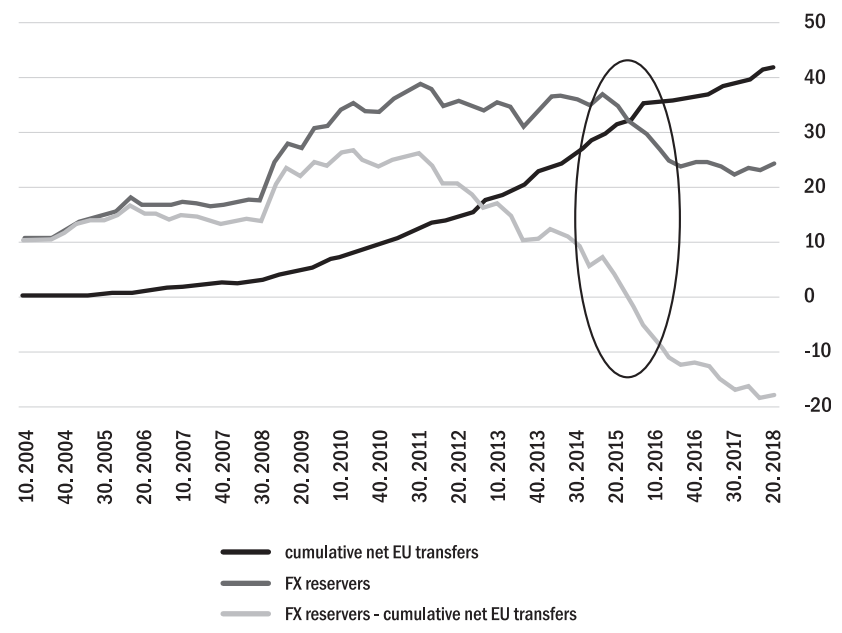

Figure 6. FX reserves of Hungary and the change of EU transfers (billion euro)

Dependency on the EU funds is especially strong in case of the investments financed by the government. Public investment is clearly a political instrument to make an impact on voters. If the local voters had elected a mayor who does not belong to Fidesz, municipality must contribute larger down-payments, or must wait longer time until pavements are built, or schools are developed. Some of them receive public funds as a gift, others may receive nothing, especially, if they elected a mayor, who belongs to an opposition party. When indebtedness of the local governments was taken over by the government, this kind of differentiation could be traced, or according to the new rules the local governments are able to issue bonds only if the government authorizes it, which is not the case in local governments of large cities managed by the opposition parties (e.g. Szeged) (Figure 7).

\subsection{About lagging productivity}

While economic performance of Hungary has improved a lot in comparison with the years of the crisis, the main source of the good results came from the application of more labour and not from productivity gains. Unfortunately, productivity did not improve during the last 7 years. Some recovery can be observed in the last 3 years only primarily because the multinationals have restarted investments (Figure 8).

The most astonishing underlying reason for the weak labour productivity results - which lagged behind the other new EU-member states - is the great difference between the productivity level of multinationals and the SME-s and other domestic enterprises. In comparison with the European countries the gap is the largest in Hungary (Figure 9).

This is due to the fact that the domestic enterprises are reluctant to invest because they do not trust in the safety of private ownership, and the economic policy of the government is unpredictable. Large multinationals can achieve good-will-type contract with the Hungarian government. I must add that this was not enough even for the multinationals to invest 


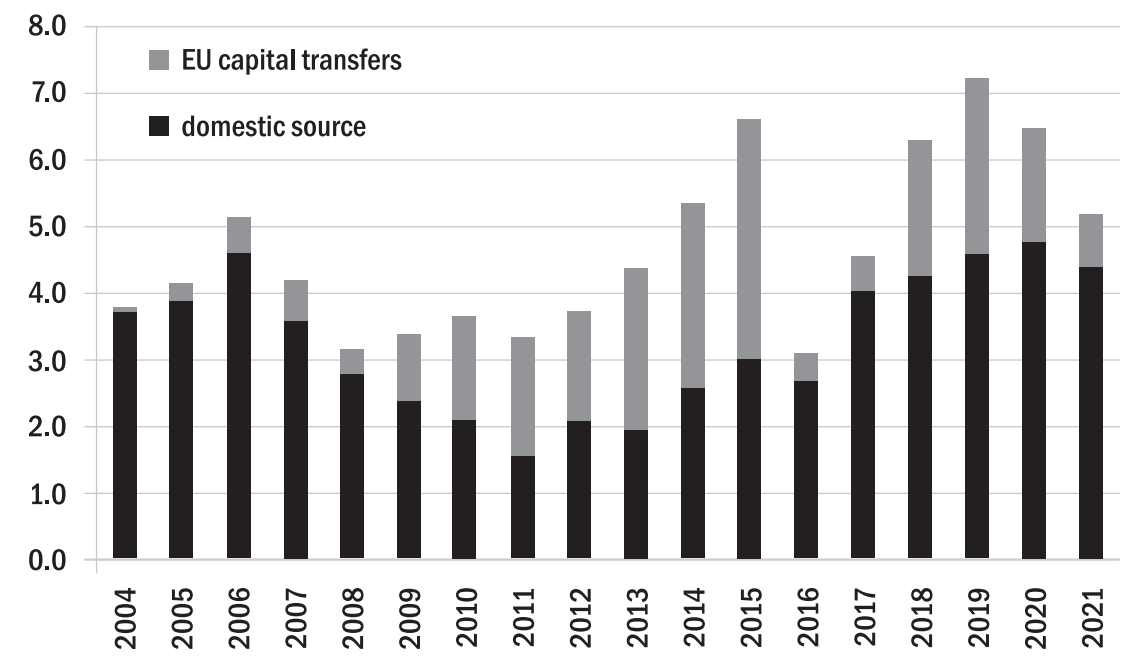

Figure 7. Distribution of resources of public investments (\% of the GDP)

continuously as they were not inclined to reinvest the larger part of their profit - which was their practice before the 2008 crisis - but they repatriate most of it. The initial difference between the domestic enterprises and multinationals did not change, as the Hungarians were also reluctant to risk assets by undertaking domestic investments.

In the last 20 years the main source of the potential output of Hungary has switched from investments to labour expansion. After the consolidation of the transition the main source of growth was investment and productivity growth. During and after the crisis the main source was the reemployment of inactive and unemployed people, in the last two years investments started

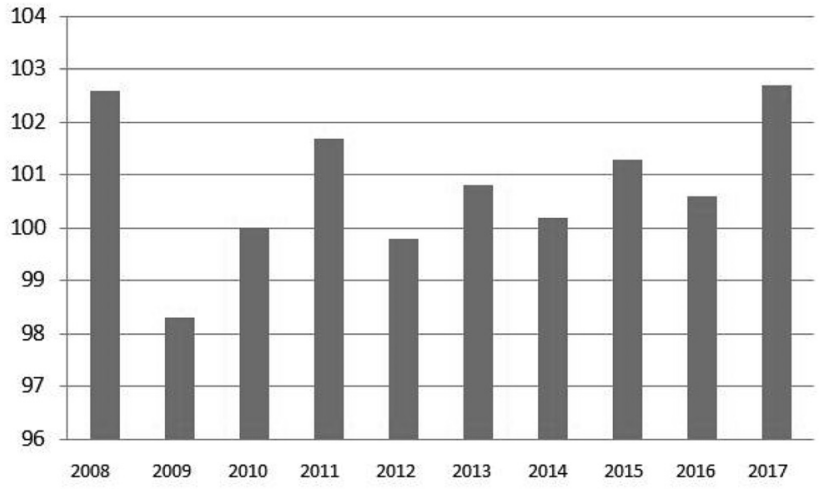

Sources: Eurostat, HCSO and own calculations.

Figure 8. Labour productivity, 2008-2017 (2010 = 100\%) 


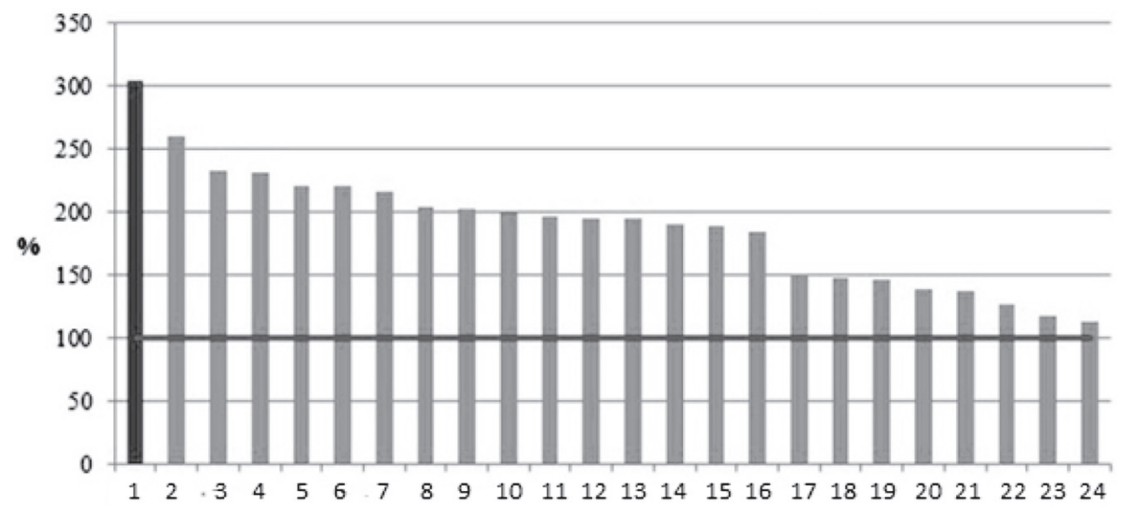

Source: HCSO.
1. Hungary
2. Bulgaria
3. Romania
4. Greece
5. Germany
6. Lithuania
7. Croatia
8. Italy
9. Latvia
10. Czech Republic
11. Netherlands
12. Portugal
13. Cyprus
14. Slovakia
15. Spain
16. Malta
17. France
18. Poland
19. Slovenia
20. Norway
21. Austria
22. Luxembourg
23. Denmark
24. Estonia

Figure 9. Productivity of multinationals in $\%$ of the domestic firms in several countries

again and now there are high expectations that productivity may become the main driving force of growth (Figure 10).

I observe that the most important outcome of the economic policy of the Orbán governments was - at least in the short-run - that the labour productivity did not grow. I can add that labour (denominator) increase came from unskilled workers and public works program, which destroyed the labour composition. On the top of that investment were postponed for almost a decade. If uncertain institutional framework and lack of predictability remains, then Hungary, which for a decade was the forerunner among the transition countries, continues to lag and can fall behind the level of Bulgaria or Montenegro (Figure 11).

\subsection{Redistribution of income and wealth for the benefit of Orbán's political family}

If I want to identify the most important political goal of the Orbán-system, I will find that all efforts for maintaining sustainable growth, avoiding the excessive deficit procedure, convincing creditors of Hungary and the members of international community is about that the Orbán's 


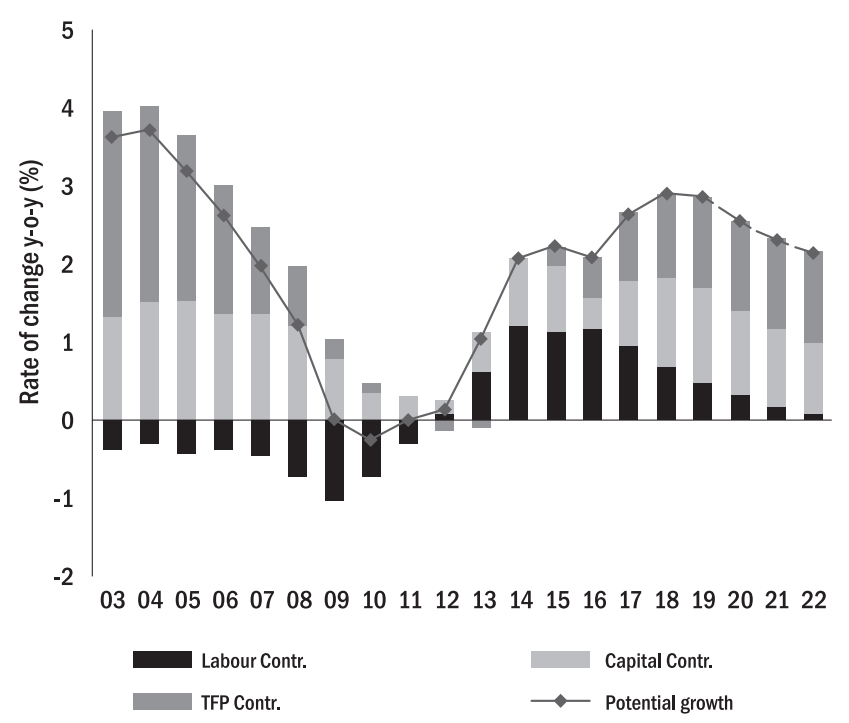

Figure 10. Development of potential GDP growth

government wishes to have a better access of income and wealth in order to redistribute it among the members of Orbán's natural and political family (Buckley - Byrne 2017). This has been a well-established pattern (The New York Times 3/11/2019) and has a long history. Fidesz party had been conceived in sin because the leaders of the Party created private-enterprises and financing them from the proceeds of the sale of their original headquarter buildings. This move not only enriched them, but they have become able to control, organise and dictate to their own party's rank and file.

"The ars poetica in brief of those who created the core of Fidesz, and of the president and the leaders of the party: Grow and get rich. The financial funds providing the party's self-sufficiency, the creation and operation of an economic base at the party elite's disposal, as well as the accumulation of wealth ensuring independence, financial self-sufficiency, and subsistence for the members of the family that make up the core of the party's leadership are all inseparable from each other. Individual enrichment that creates and guarantees economic sovereignty, the increasing growth of laws granting the right of disposal over property, and the widening legal practice of possession and disposal, signifying an economic base for the interests of the ruling political organization, are all interconnected. In this context, the party is a political enterprise for the prosperity of families controlling the party and for their enrichment, while at the same time the prosperity of these families is a guarantee that they will be capable of achieving and maintaining a concentration of political power necessary to gain acceptance and legitimization of the accumulation of family wealth in the party and politics. Through the founding of these shady "friendly companies," they have attempted to achieve at least three goals. Not only was it their goal to create the economic foundations for the relatives of the Fidesz leaders, but it also allowed the members of the family to become involved in the privatization process. While the party could not compete in privatization tenders to provide the economic foundations for 


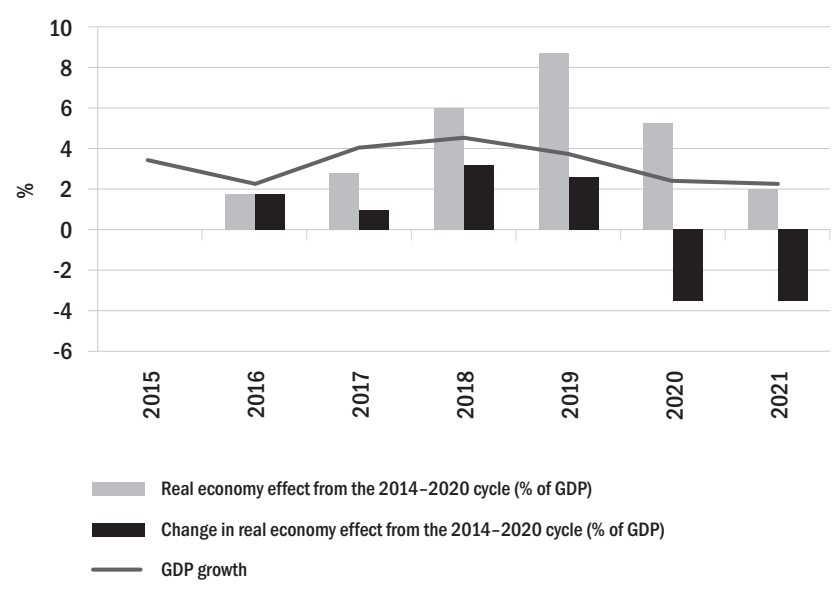

Figure 11. Economic influence of EU transfers, year-by year change and GDP growth, \%

personal enrichment, members of the family could. The third goal, of course, is the implementation of a solution known since the wars of religion: Whoever owns the property, owns the party. As students have learnt from the age of religious wars, whoever owns the land decides the religion that those living on the land should follow (cuius regio, eius religio)" (Csillag 2017: 279-280).

The same procedure was applied during all four governments of Orbán. In the first period, the non-performing assets of banks or liquidated enterprises has been sold at a bargain price for the members of the political family, while the most profitable 12 state farms were privatized to the members of the political family of Orbán (K-monitor). The management of the Budapest airport was also taken back by the state from PPP framework, for the sake of having access to the most profitable activities. Tobacconist's shops concession has been redistributed among the most loyal members of Fidesz (Hungarian Spectrum 2013.)

The largest bulk of public procurements is now won by the closest sponsors of Orbán (Visegrad revue 2018). Special public tender was organized for the benefit of Orbán's son-in-law in the public lightning system renovation projects businesses, which is under thorough investigation by the OLAF, the Fraud Investigation Bureau of the EU (Politico 19/04/2019). Harbours, large pieces of agricultural lands and building sites at the Lake of Balaton had been privatized by the local governments for the members of Orbán's family (included his son-inlaw). His fellow countryman and his - not so - silent partner Mr. Mészáros (Hungary Today 2018) (previously mayor in his village) became the richest person in Hungary from a simple mechanic. Mr. Mészáros is not only the luckiest person (Daily News Hungary 2018) in Hungary to win almost every public procurement, where he and his firms participate, not only he is invited to take part in all large-scale investment in the country, he is offered to accept the ownership of foreign companies (from the Power Plant of Mátra to the Hotel-Chain of Hunguest), but he has become a genuine competitor of the largest Hungarian Bank: the OTP as well. (Intelligence News 2018)

Orbán has emphasized that he has learnt the lesson after the collapse of the first democratically elected right-wing or conservative government of Hungary: the Antall-government. 
According to Orbán the cause of the failure of the Antall-government was that it was not able to build around itself a friendly economic network of large businesses (oligarchs), and as the consequence of the lack of this network it was forced to pursue a politics which is accepted by the international business community or the multinationals, and as a matter of fact it was not able to accomplish the important goal of building national middle class in the country.

This demagoguery conceals the effort of Orbán to base his power on national oligarchs depending on him personally. There are efforts to make an inventory about the wealth of Orbán's and his political family. These efforts are at least ambiguous, as almost all oligarchs are dependent on Orbán and are willingly ready to offer their belongings if it is ordered, as it happened in the case of the establishment of media monopoly, or in the case of transfer of the wealth of Mr. Spéder or Mr. Simicska (Politico 28/6/2017). That is one of the most important difference between the political goals, policy and political strategy of the Conservative Polish regime of Kaczy'nski and the regime of Orbán. This effort can be illustrated with the dispute between Orbán and his most important former comrade and brother in arms: Mr. Lajos Simicska, or the fate of Mr. Zoltán Spéder, the former Chairman and the chief owner of the mortgage finance bank, FHB, who suddenly fell out from the favour of Orbán because he did not want to surrender his control over the media subsidiaries of his personal empire.

\subsection{About well-being of clientele of Orbán}

Result or consequence of Orbán's four governments is an artificially created and privileged ruling class from the family of Orbán and his friends. As time went by, this inner circle has been widened to the political family, whose members are the winners of local tenders and local government projects. The demagoguery of building a new middle class motivated the introduction of the flatrate tax system in PIT, which also includes generous tax deduction for children. The efforts of getting rich by the members of political family and the redistribution of revenues through the taxation system resulted that the share of the highest income decile in the income of the country increased, the better-off deciles lost, while the share of the lowest income deciles has dropped.

Until 2008, Hungary used to have a progressive-rate PIT system. This PIT system changed two years before the second Orbán-government, partly due to the influence of other East-European countries flat-tax reforms, partly to decrease the very high tax-wedge on the Hungarian personal incomes and a flat tax had been introduced. The second Orbán-government (from 2010) changed again the newly introduced flat-tax, and implemented a flat-tax in combination with tax-deductibility based on number of children. The Orbán-government also introduced a well-tailored, tendentious change in taxation of personal incomes (Figure 12).

From the end of 2013 some changes have been introduced to buy the votes of the poorest strata of the society. The public work programs became robust, the number of participants increased from 100,000 to 220,000, the deductibility levels for children in PIT also have been raised, and - as I mentioned earlier - the transfer of the EU funds also doubled, which influenced the size of economic growth. According the HCSO, the inequality between the poorest and the wealthiest strata (SS80/SS20) went up from 3.94 (2010) to 4.35 (2013) then it diminished a little bit to 4.25 (between 2014 and 2017), but it started to increase again to 4.4 (2018). The main underlying reason for the increase of inequality is the robust increase of revenues in the highest income decile, in which I could identify the widest representation of the political family of Orbán.

If I apply the famous formula of Pigou (1920/2001) about economic welfare of the population: a) Economic welfare increases if the size of national income increases without 


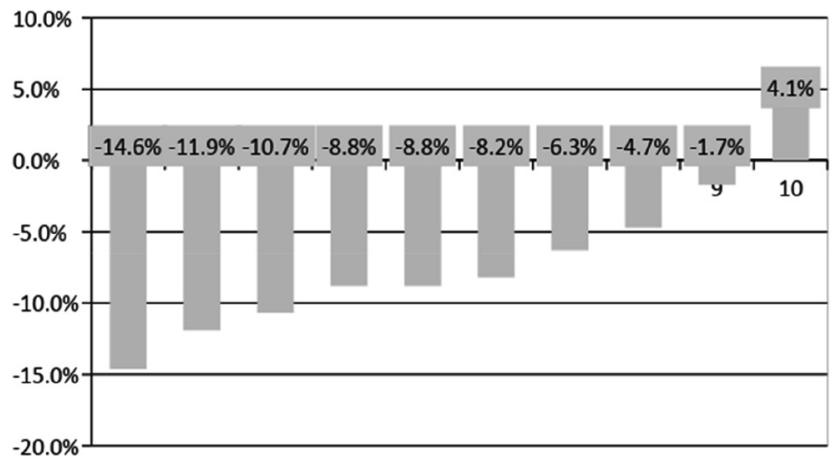

Note: From the poor for the better-off, according to the deciles on HUF basis.

Source: Eurostat; Privatbankar.hu.

Figure 12. Change of real income of certain social strata between 2009 and 2013

"worsening" the distribution (efficiency condition); and b) Economic welfare increases if distribution "improves" while size of national income does not decline (equity condition). It turns out that the Orbán's economic policy neither serve public nor economic welfare. If neither higher rate of growth and higher national income could be reached nor the distribution of income improved, the only reason of the application of public force of the state power is to redistribute wealth and income for the benefit of the political family of Orbán and his relatives and friends. This phenomenon is called state capture (Hellman - Kaufman 2001) and it had seemed to be the highest risk throughout of the whole transition period in the previous socialist countries. It turned out that Hungary which avoided this path in the first 20 years of transition (from 1989 until 2010) became the front runner in this sense from the second government of Orbán.

\subsection{Creation of a new type of duality in the enterprise sector}

From 1968 there was a decentralized economic system of socialism in Hungary. This was the only country among the economic association of socialist countries (CMEA) where mandatory planning command system was largely abolished, and even the state-owned enterprises became semi-autonomous economic units. The previously highly centralized nature of the command system had a side effect: centralization of economic organizations into huge economic units. The consequence was that a special duality (in size) became a characteristic of the Hungarian enterprise sector. The state-owned enterprises kept their large, overcentralized organization, while cooperatives and newly established and liberalized (1982) private businesses were much-much smaller in terms of employment or capital (Voszka 1988). This duality in size remained one of the main problems of transition, as selling of large state-owned enterprises during the privatization process meant that they could be sold only to foreigners, or through the stock-exchange in the form of public offering.

This inherited duality had been changed during transition: at first $60 \%$ of the large state-owned enterprises had to start a bankruptcy-proceedings, half of them were liquidated. Then a sharp 
difference had been borne as multinationals established subsidiaries, which were much more competitive than the ordinary home-owned counterparts; the foreign owned or foreign participated companies' capital, profitability and performance was much higher than the ordinary Hungarian enterprises. Two thirds of the export, $60 \%$ of the value added was produced by them, while they employed $15 \%$ of the labour force. This split between enterprises was always a reason for disputes among the political parties, as foreign owned companies had got tax-holidays or tax-rebates proportionally with the size of investment according the European Union legislation. As the Hungarians were not able to invest the same amount of money they were not entitled to the same preferential treatment.

The economic policy of the Orbán-government started to apply a new distinction: those industries which sold their production on the domestic-market (mainly service-industries: financial intermediaries, retail-trade supermarkets, energy-supply and energy-distribution companies, telecommunication companies andpublic utility companies) came under a special heavy taxation which forced their owners to sell their ownership rights to the well-established circles of the Orbán political family, or to serve the Orbán-system by placing adverts in the Orbán-friendly newspapers or TV-channels. Exporting firms (mainly manufacturing companies) are in turn were encouraged to sign cooperation agreements with the government and promise that they would not reduce their production and investments would not lead laying off or firing large number of their workforce. This sharp distinction is the repetition of an old traditional trick, which emphasized the significance of the productive industries in contrast to the unproductive ones. But the distinction is not just a simple observation, but a main driver of the economic policy.

This duality is a primary consequence of the influence of the Orbán political family in the economy, it is also experienced in public procurements. According to the analysis of the Transparency International (quoted by Buckley - Byrne 2017), the overwhelming majority of the largest value projects are won by the firms which belong to the closest circle of Orbán. In most cases it means his friend Mr. Mészáros (Hungarian Spectrum 2018), who comes from the same village and who is so "talented" that he made a billion euros worth of accumulated assets from scratch. Beyond that banks (BneIntelliNews 2020), companies in the construction industry, supermarkets, real-estate companies, even TV-channels and newspapers are belonging to his portfolio today, notwithstanding he is a gas tube fitter by profession. His company will manage one of the largest new railway-project in Hungary, the reconstruction of the railway line between Budapest and Belgrade (Portfolio.hu), as a part of the Chinese Belt and Road initiative (BRI) which is going to be financed by a Chinese loan.

While a new duality has appeared (productive versus unproductive; companies selling their production on the domestic market versus exporting companies) (Mihályi-Szelényi 2019), the traditional duality of subsidiaries of the multinationals and the Hungarian controlled industries; large enterprises and the SME sector remained. The duality resulted in that large companies controlled by the multinationals produces four-fifth of the Hungarian exports and their productivity level is at least 3 times higher than their Hungarian competitors in the same sectors and subsectors, their capital base is also 3-4 times higher, while the profitability of them is also 3 times higher (Békés - Muraközy 2018; Muraközy et al. 2019). The EC regularly collects data about the performances of the SME business in its SBA Facts Sheets (SME Report, EC). According to the last report, it emphasizes the negative differences from the EU average, while efforts have been taken is the latest years to achieve some closing ups. 
The difference in productivity and competitiveness has not changed between the Hungarian and foreign owned companies due to the fact that so called "national champions" are nominated by the Orbán-government in the course of public procurement (previously the companies Vegyépszer, then Közgép, now Duna Aszfalt in the construction of motorways and building railways), or any competition organized by the government. As enterprises are not forced to innovate and to invest, their productivity has not improved. They do not and cannot take part in any foreign competition. They are contracted by the central and local governments. It is not a surprise that OLAF very often find irregularities in the tendering processes or some suspicious tenders.

\subsection{To rule the present, do not bother with the future}

In Hungary, it became a tradition that everyday people are keen on having their consumption at a relatively high level, while savings and as a matter of fact their investments are at low level. It was the tradition between the two world wars, because the largest number of the population was poor, even there were many who cannot afford food for themselves, in large cities there were soupkitchens, in villages men were forced to work for food only. After WW 2 impoverishment went on among the middle-income strata of the society as well, which made the situation manageable for the communist to introduce the Soviet type highly centralized planning command system in which private consumption meant the same food, clothes and housing for everyone as investment into the industry (heavy industry) was the final goal of the whole system (Kornai 1992).

The overemphasized character of investment had to be financed from the forced (national, or public) savings of the people, which had been achieved at the expense of consumption. As wages had been calibrated according to the fixed level of consumption and fixed pricing of consumer goods, there were no room for private savings, only if the durable goods were not out of stock and everyday people had to wait and during waiting they refrained from consumption, which resulted a forced form of savings. After the Hungarian Revolution in 1956, the Kádár regime had changed the system to pour oil on the troubled water of the political feelings of people and Hungary became the "cheerful barrack" in the Communist camp. In Hungary, the everyday consumption of the people became important, because "if the stomach is not empty people will not fight for their freedom", was the slogan of the Kádár regime. But consumption-orientedness always means that present day's decisions are much more important than any decision which might change the future. The old soviet-rule tradition (everything is decided over the level of the layman by the Central Committee of the Party) had been replaced by a new dichotomy: do not bother about of your future, consume NOW! This tradition of the Kádár-era (1957-1990) survived after the great transformation (Kornai 2000) and it became one of the main obstacles of rational reforms.

The Orbán's regime learnt the Kádár's lesson well, as it started to buy the votes of those strata of the society which are interested to keep their social standard of living in exchange of leaving the political arena. Unemployed will get the possibility of social work if they vote for Orbán, middleincome families will get tax-reliefs if they are willing to vote for Orbán, private savers will earn a premium if they buy bonds of the treasury instead of investing their money on private bankaccounts or private pension funds. The consequence is falling productivity (Figure 13).

If the population is inclined to concentrate its effort on the present day consumption, they are allowed to pursue their policy, but it is controlled by every possible channel (tax-reliefs, employment-rules, dependency from state aid, rate of consumption and savings). The future of the nation is controlled from above, as only those enterprises can grow, which are dependent on Orbán, or are enjoying territoriality as a consequence of their export. Only those entrepreneurs 

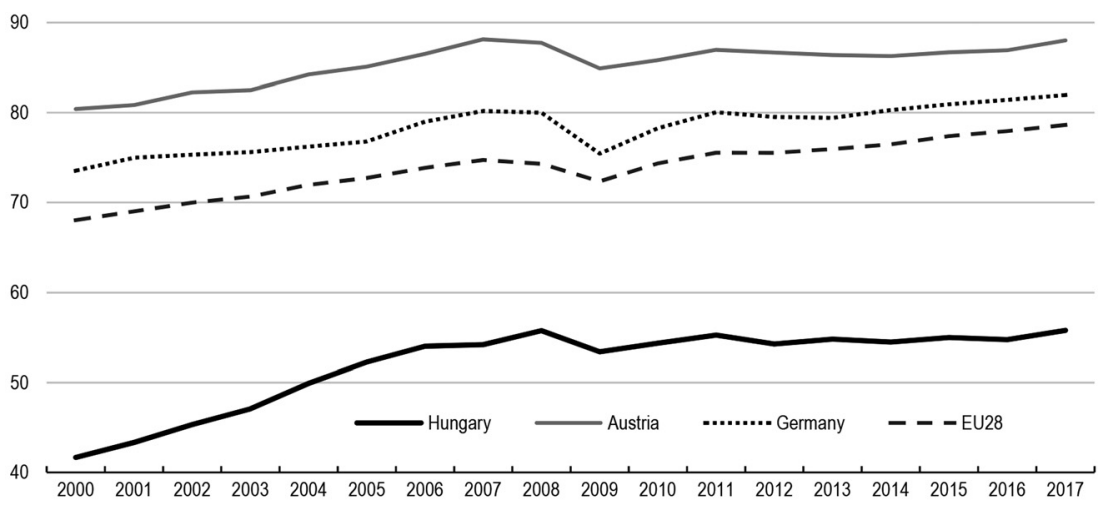

Source: OECD (2018), OECD Productivity Database.

Figure 13. Productivity is falling (Real GDP per persons employed, in USD thousand, constant prices, 2010-PPS)

are brave to invest into their own enterprises who are trusted by Orbán, or those who are too big that Orbán is not able to control them. If anyone gives up planning of the future it might have a chance to survive and consume. If you live only in and for the present day then you can prosper. Individual planning about the future is controlled, that's why the Orbán economic system is quite vulnerable if harsh and sudden changes are coming.

\section{CONCLUSION}

I was able to identify six most important genuine goals of the economic policy of Orbán's government, namely:

- to regain/maintain the possibility to pursue an independent, uncontrolled, sovereign economic policy;

- to ensure the uncontrolled and unrestricted utilization of public money and public assets;

- to redistribute income and wealth for the benefit of Orbán's political family, without the risk of excessive deficit procedure;

- to build and strengthen the political base's unconditional support based on $2 / 3$ majority of the MP-s;

- to create a new duality in the market sector;

- to rule present day and do not bother what will happen tomorrow.

The improving macroeconomic performance of Hungary (robust rate of growth, diminishing deficits and unemployment, low rate of inflation) is the necessary precondition to achieve these above-mentioned goals. To achieve the improvement of macroeconomic indicators the government undermined the soft preconditions of economic growth: 
- instead of competition there are artificial monopolies,

- instead of strengthening the rule of law, the law of Rule has been built,

- instead of overall safety of private ownership the differentiation of owners became the practice,

- instead of decentralized decisions and efforts of private entrepreneurs, the centralization of decisions and assets is strengthening.

Is there a chance that this autocratic regime will last forever, or it is so fragile, that if there is a financial crisis again, it is not able to finance itself and will collapse? It seems that this economic policy could be continued for long without any serious risk at the home market. The only risk is outside risk. Among them the first is that if Hungary is not a member country of the EU anymore, the transfers coming from the EU are not available anymore, and it could be more serious if it is accompanied by a serious financial crisis in the world market. It looks like that the Orbán regime tries to play a double role for the illusion of independence (at least in its internal affairs), while in real critical situations it accommodates itself to the expectations of the big players in Brussels. The risk of break with the EU is low, as the main factor of stabilization of Hungary is the membership in the EU. Even the EC is also balancing, avoiding the very rude form of influence, experiencing the accommodation of the Orbán regime. Taking into consideration the flexibility of the Orbán regime according to the expectations of the EU, the financial fragility of the regime could improve. Only if in a complicated financial situation, in a financial turmoil of the markets accompanied by the collapse of EU relationship, which needs a very serious crisis management, or harsh, heavy cuts could result the failure of the Orbán regime. If the seemingly improving indicators are not sustainable anymore due to any financial crisis or the lock down continues and the artificially profitable enterprises of Orbán political family have to compete, the whole economic and political system could collapse as it is based on redistribution of additional incomes coming from the EU and recentralized income of the society not belonging to the Orbán political family. From that very end, from this aspect of economic policy of the Orbán regime, it is not sustainable and all fundamentals or the good performance of the Hungarian economy is quite vulnerable (compare Acemoglu - Robinson 2012). That is the reason why the Hungarian macroeconomic policy cannot be copied by other countries in transition because these autocratic regimes are very fragile as their own economic base for a better performance is quite weak.

\section{REFERENCES}

Acemoglu, D. - Robinson, J. A. (2005): Economic Origins of Dictatorship and Democracy. Cambridge: University Press.

Acemoglu, D. - Robinson, J. A. (2012): Why Nations Fail. The Origins of Power, Prosperity and Poverty.

New York: Crown Business.

Acemoglu, D. - Robinson, J. A. (2019): The Narrow Corridor. States, Societies, and the Fate of Liberty. New

York: Penguin Press.

Acocella, N. (1998): The Foundations of Economic Policy. Cambridge: Cambridge University Press. 
Alesina, A. - Perotti, R. (1994): The Political Economy of Budget Deficits. NBER Working Paper Series, No. 4637.

Békés, G. - Muraközy, B. (2018): The Ladder of Internationalization Modes. Evidence from European Firms. CEPR Discussion Papers, No. 12639.

Bne IntelliNews (2020): https://www.intellinews.com/orban-s-allies-to-create-new-universal-bank-tochallenge-top-lender-otp-bank-152970/.

Bokros, L. (2013): Accidental Occidental. Economics and Culture of Transition in Mitteleuropa, the Baltic and the Balkan Area. Budapest - New York: Central European University Press.

Bokros, L. (2014): Regression, Reform Reversal in Hungary after a Promising Start. In: Åslund, A. Djankov, S. (eds): The Great Rebirth: Lessons from the Victory of Capitalism over Communism. Washington, DC: Peterson Institute for International Economics, pp. 39-53.

Bokros, L. - Dethier, J. J. (1998): Public Finance Reform during the Transition. The Experience of Hungary. Washington, DC: The World Bank.

Bozóki, A. (2012): Virtuális köztársaság (Republic as a Virtual Phenomenon). Budapest: Gondolat Publishing House.

Buckley, N. - Byrne, A. (2017): Viktor Orban's Oligarchs: A New Elite Emerges in Hungary. Financial Times, December 21, 2017. https://www.ft.com/content/ecf6fb4e-d900-11e7-a039-c64b1c09b482.

Byrne, A. (2015): Hungary under Fire over Growing Use of Public Works Labourers. Financial Times, August 13, 2015. https://www.ft.com/content/9ab6dd04-3c1d-11e5-bbd1-b37bc06f590c.

CASE (Center for Social and Economic Research) (2017): Study and Report on the VAT GAP in the EU-28 Member States. Final Report (TAXUD/2015/CC/131).

Csillag, I. (2013): Deficit, a szándékon túli eredmény (Deficit, Result Beyond Intention). Budapest: Kalligram Publishing House.

Csillag, T. (2015): Understanding "Orbanomics" Economic Nationalism in the Era of Globalization. Budapest: CEU Thesis. file:///C:/Users/CsillagI/Downloads/csillag_tamas.pdf.

Csillag, I. (2017): Getting Rich as Mission: Swapping Elites on a Family Basis. In: Magyar, B. - Vásárhelyi, J. (eds): Twenty-Five Sides of a Post-Communist Mafia State. Budapest: CEU PRESS - Noran Libro, pp. 279-295.

Csillag, I. (2018): Háttal a holnapnak (Backwards to Tomorrow). Budapest: Kalligram Publishing House.

Daily News Hungary (2018): https://dailynewshungary.com/lorinc-meszaros-silently-admitted-being-oneof-the-richest-people-in-hungary/.

Direkt 36 (2018): https://www.direkt36.hu/en/rejtett-allami-munkakbol-is-jott-penz-az-orban-csaladgyorsan-szerzett-milliardjaihoz/.

European Commission (2017): SME Business. SBA Facts Sheets, file://C:/Users/CsillagI/Downloads/ Hungary\%20-\%202017\%20SBA\%20Fact\%20Sheet.pdf.

Hellman, J. - Kaufman, D. (2001): Confronting the Challenge of State Capture in Transition Economies. Finance \& Development, 38(3) and IMF econ.papers. https://www.researchgate.net/publication/ 245768896_Confronting_the_Challenge_of_State_Capture_in_Transition_Economies.

Hungarian Central Statistical Office (HCSO) (2016): Indicators of Sustainable Development for Hungary. http://www.ksh.hu/docs/eng/xftp/idoszaki/fenntartfejl/efenntartfejl16.pdf.

Hungarian Spectrum (2013): http://hungarianspectrum.org/2013/04/25/hungarys-national-tobacco-shopswho-are-the-happy-recipients-of-the-concessions/.

Hungarian Spectrum (2018): http://hungarianspectrum.org/2018/01/21/the-spectacular-business-career-oflorinc-meszaros/. 
IMF Press Release (2015): Hungary Repays Early Its Outstanding Obligations to the IMF. https://www.imf. org/en/News/Articles/2015/09/14/01/49/pr13306.

IMF Mission Statement (2016): Hungary: Ex Post Evaluation of Exceptional Access under the 2008 Standby Arrangement. https://www.imf.org/en/Publications/CR/Issues/2016/12/31/Hungary-Ex-PostEvaluation-of-Exceptional-Access-Under-the-2008-Stand-By-Arrangement-24987.

K-Monitor (2020): http://k-monitor.hu/database/cimkek/piszkos-tizenketto-agrarcegek-privatizacioja.

Kopits, G. (2012): Can Fiscal Discipline Be Reconciled with Fiscal Sovereignty? Acta Oeconomica, 62(2): 141-160.

Kopits, G. (2013): Restoring Public Debt Sustainability: The Role of Independent Fiscal Institutions. Oxford: Oxford University Press.

Kornai, J. (1992): The Socialist System. The Political Economy of Communism. Princeton: Princeton University Press and Oxford: Oxford University Press.

Kornai, J. (2000): Paying the Bill for Goulash-Communism. Vol. II. of the Series: Evolution of the Hungarian Economy 1848-1988. New York: Atlantic Research and Publications and Columbia University Press.

Kornai, J. (2017): Látlelet. Tanulmányok a magyar állapotokról (Diagnosis. Studies on the Hungarian Situation). Budapest: HVG Books.

Körösényi, A. (ed.) (2015): A magyar politikai rendszer - negyedszázad után (The Hungarian Political System - after 25 Years). Budapest: OSIRIS Publishing House.

Magyar, B. - Vásárhelyi, J. (eds) (2016): Twenty-Five Sides of a Post-Communist Mafia State. Budapest: CEU Press - Noran Libro.

Mihályi, P. - Szelényi, I. (2019): Rent-Seekers, Profits, Wages and Inequality. London: Palgrave Macmillan.

Muraközy, B. - Bisztray, M. - Reizer, B. (2019): Productivity Differences in Hungary and Mechanism of TFP Growth Slowdown. EC Publication. https://publications.europa.eu/en/publication-detail/-/publication/ 1696744b-22b3-11e9-8d04-01aa75ed71a1/language-en/format-PDF.

Orbán, V. (2018): New Government's Economic Policy to Follow “Matolcsy School”. Hungary Today, April 11, 2018.

Pigou, A. C. (1920/2001): Economics of Welfare (Palgrave Classic in Economics). London: Palgrave Macmillan.

Political Capital (2018): Fidesz Economic Policy Risks. 11.06.2018. http://www.politicalcapital.hu/news.php? article_read $=18$ article_id $=$.

Politico (28/6/2017): https://www.politico.eu/article/viktor-orbans-former-bff-vows-to-take-down-fidesz/.

Politico (19/04/2019): https://www.politico.eu/article/istvan-tiborcz-viktor-orban-olaf-eu-pursues-orbanson-in-law-case-despite-hungary-ending-probe/.

Sárközy, T. (2019): Illiberális kormányzás a liberális Európai Unióban - Politikailag igen sikeres túlhajtott plebejus kormányzás - a harmadik Orbán-kormány, 2014-2018 (The Illiberal Governance in the Liberal European Union 2014-2018). Budapest: Park Publishing House.

Schering, G. (2018): Hungary's Regime is Proof that Capitalism can be Deeply Authoritarian. Open Democracy, April 10, 2018.

Surányi, Gy. (2018): Ten Years After the Crisis in Hungary. Acta Oeconomica, 68(S2): 121-142.

Szelényi, I. (2019): Tanulmányok az illiberális posztkommunista kapitalizmusról, 2014-2018 (Studies about the Post-Communist Capitalism, 2014-2018). Budapest: Corvina Publishing House.

The New York Times (03.11.2019): https://www.nytimes.com/2019/11/03/reader-center/eu-farm-subsidyreporting.html? searchResultPosition $=1$.

Ungváry, R. (2014): A láthatatlan valóság. A fasisztoid mutáció a mai Magyarországon (The Invisible Reality. The Mutation of the Fascist System in Hungary, Today). Bratislava: Kalligram Publishing House. 
Visegrad Revue (2018): http://visegradrevue.eu/how-the-orban-government-eradicated-corruption-inhungary/.

Voszka, É. (1988): Reform és átszervezés a nyolcvanas években (Reform and Reorganization in the Eighties). Budapest: Közgazdasági és Jogi Publishing House.

Zakaria, F. (1997): The Rise of Illiberal Democracy. Foreign Affairs, November-December: 22-43.

Wojciechowski, W. (2017): Orbanomics, or Unfulfilled Dream of the Hungarian Economic Power. Civil Development Forum - FOR Analiza, No. 22. Warsaw.

Open Access. This is an open-access article distributed under the terms of the Creative Commons Attribution 4.0 International License (https://creativecommons.org/licenses/by/4.0), which permits unrestricted use, distribution, and reproduction in any medium, provided the original author and source are credited, a link to the CC License is provided, and changes - if any - are indicated. (SID_1) 